\title{
THE SPACE OF WROCŁAW IN THE CONTEXT OF ECC 2016 MICROGRANTS PROGRAM REALIZATION - RESEARCH CONCLUSIONS
}

\author{
AGNIESZKA WIESZACZEWSKA \\ Faculty of History and Pedagogy, University of Wroclaw, \\ Uniwersytecki Square 1, 50-137 Wrocław, Poland. \\ E-mail address: agnieszka.wieszaczewska@uwr.edu.p
}

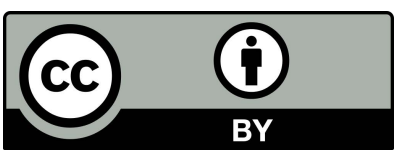

\section{ABSTRACT}

In 2016, the title of the European Capital of Culture was awarded to Wrocław. To celebrate the year of 2016 citizens could partake in many cultural initiatives prepared specially for this occasion. The proposals aimed at the people of Wrocław included the ECC 2016 Microgrants program, under which any citizen could realise and gain funding, as well as obtain administrative and promotional support for their designed cultural activity. Field studies conducted during the first two editions of the program served as the basis for a report, which includes conclusions regarding the perception of the urban space submitted by task performers. Low-budget cultural activities proved to be an excellent pretext for the citizens to reconsider the issues of public space in Wrocław, access to cultural events or the manner of constructing official discourses about the city and its space. This article focuses on the issue of space in the context of Microgrants 2016 and presents the outcomes of the fieldwork.

Key words: European Capital of Culture, space, culture, public space

\section{INTRODUCTION - URBAN PUBLIC SPACES}

At the start of the Industrial Revolution, urban centres in Europe began to expand rapidly, and this process has continued to the present day. "The world is continually becoming more urban - the population in areas and estates classified as urban is increasing. The growth rate is unprecedented. The rise in the number of megacities - cities a with populations over ten million - is a spectacular manifestation of modern urbanisation in terms of population concentration" (Grochowski, 2013, p. 9). It is not surprising, therefore, that cities get more attention from the press, in panel discussions and debates, regarding the manner of development of urban centres, and urban studies degree courses continue to be introduced into university curricula. The cities themselves are facing new problems and the pressure of urbanization affects all the issues connected with life in the city, such as spatial, economic or environmental, as well as cultural and social aspects of 
the city. How are we to stimulate the cultural development in cities? How can we make them accessible for everyone? How do we make cities more attractive for tourists through the available cultural activities? These are only some of the questions regarding the association of culture with the city. Nowadays, culture has become an integral and continuously more important factor in the development of large, medium-sized and small cities, as well as a "building material constituting the concepts of the urban, civic and European identity. Culture is crucial for proper functioning of larger communities" (Filar, \& Kubicki, 2012, p. 135).

One of the most important issues of today's urban planning is the role, condition and destination of public spaces in cities - both in metropolises and small centres. It is widely considered that moving away from the Athenian idea of the agora, where people could meet to freely exchange their concepts, organise and experience things together, is caused by economic changes, among other things. When comparing the contemporary city with an international corporation, Richard Sennet demonstrated that what once was one of the essential features of urban centres - the opportunity for strangers to meet - has gradually started to disappear. And it is characteristic both of large, present-day capitalist companies, as well as cities. Sennett (2007) stated that:

The sense of fraternity as a shared fate, a durable set of common interests, has been weakened. Socially, the short-term regime produces a paradox. People work intensely, under great pressure, but their relations to others remain curiously superficial. This is not a world in which getting deeply involved with other people makes much sense in the long run.

The American sociologist considers encounters not only as physical intimacy, but, primarily, as an opportunity to establish relationships of varying intensities. The decline of the functions of traditional urban spaces is also connected to their gradual privatization, architectural procedures aimed at discouraging people from using them, or cultural changes (for instance, the presence of television in almost every household is considered by many the reason why people do not want to meet in a public space to establish relationships).

Public space should be distinguished from the city by a couple of features. First of all, it needs to be accessible to everyone - every citizen has the right to use it, as long as they are not breaking the code of conduct pertaining to such places, adopted by a given community. Streets, parks, squares and plazas are basic types of public spaces in cities. Apart from being accessible, a public space must also be authentic (meeting the real needs of citizens) and safe. A public space also needs to be "possible to grasp: by looking at it, taking a walk in it, by the possibility of bringing people, who can later be recognised and possibly identified with, together (...) as well as through elusive thoughts and deeper reflection" (Frysztacki, 2005, p. 152).

Cultural initiatives in the public space can be a factor sustaining the local communities occupying and enriching those places. Sometimes, these initia- 
tives can lead to the establishment of new relationships. In the case of people living on the same street, estate or neighbourhood, where the only thing that the residents share is "the same address", cities cannot be considered communities. After all, a "community consists of people socially interacting and relating to each other within a given area and having common interest or a sense of group and spatial identity as an element of common bonds" (Starosta, 1995, p. 31). When talking of a real local community, it turns out that spatial proximity is not as important as a certain type of closeness of its residents. Theobald \& Siskar (2010) state that:

The degree to which a particular place in fact constitutes a community depends not on the number of people living in close proximity to one another, but on the amount of life circumstances that are shared. A small number of ranch families spread out across vast spaces within a particular watershed may be more of a community than a densely-populated suburb (p. 198).

Charles Montgomery considers the lack of joint cultural and social initiatives within the so-called scattered cities as one of the main reasons for citizens' declarations regarding their low life satisfaction. According to his diagnosis, it is because of the Bauman's "neighborhood without neighbors" concept, that Americans are continuously less satisfied with their surroundings. Szatan (2012) explains that this term describes

(...) people, who live near each other in close proximity, but remain isolated when it comes to other things, and do not know each other well. The lack of common interests minimizes the role of mutual commitments among people living in the same area (p. 100).

However, Montgomery optimistically depicts how joint initiatives improved the situation of unsatisfied residents in some expansive American suburbs. Their sense of security, the level of trust in neighbours and the general evaluation of their life situation have improved straight away (Montgomery, 2015).

In this article I would like to outline the results of the research conducted by the University of Wrocław research team in 2014, concerning one of the cultural programs implemented as part of the European Capital of Culture 2016 initiative in Wrocław. The "ECC 2016 Microgrants" program aimed to increase the degree of citizen participation in the celebration of the year of 2016, as well as to encourage them to take part in the city's cultural life, basically to co-create it. The program also aimed to revitalize the public space in Wrocław by helping the citizens implement their own cultural initiatives, for instance in their immediate surroundings (districts, estates, streets, or buildings). The conclusions presented concern one of the many issues addressed by the researchers, namely the people involved in the urban space narrative. 


\section{"ECC 2016 MICROGRANTS" PROGRAM AS AN EXAMPLE OF LIMITED SUPPORT FOR CULTURAL INITIATIVES}

The idea to include cultural heritage and tradition of particular European cities in the processes of intracontinental integration was articulated in the 1980s. The idea of Melina Mercouri, the then Minister of Culture of Greece, has been widely acknowledged and started to function under the name of the European City of Culture since the beginning of the new millennium. The belief that cultural heritage can support the continental bonding process had obviously surfaced previously. K. Kowalski, an ethnologist, mentions this concept in his work (2013):

Notions from the analytic language of social studies appear in the institutional discourse of the EU. Along with heritage, it is culture, identity and social cohesion that play a big role in this discourse, since they have already preserved their descriptive and performative role and persuasive position. They became mobilizing metaphors used to craft European culture, European identity and European awareness (p. 11).

The European Capital of Culture program was launched in 2000. Its main idea is intra-European integration based on intercultural dialogue and bringing together diverse cultures, as well as promoting and maintaining Europe's cultural heritage. The city chosen as the European Capital of Culture for the entire year becomes the cultural centre of the entire continent, and the place where miscellaneous cultural initiatives are held, which show the richness of the chosen Capital's heritage. Edwin Bendyk (2012) questions the entire concept, by calling the competition for the title of the European Capital of Culture:

(...) a strange initiative, [in which], cities (...) take part in an infantile venture - a contest, where they need to show off in front of a more or less arbitrarily chosen jury. And all this for what? To prove, just like schoolchildren, that they have done their homework when it comes to culture, and that they can be promoted to the next grade (p. 97).

There are more people voicing their objections against the European Capital of Culture, which does not change the fact that Polish cities dream of this title. Since 2008, the following cities have applied to participate in the contest: Białystok, Bydgoszcz, Gdańsk, Katowice, Lublin, Łódź, Poznań, Torun, Szczecin, Warsaw and Wrocław.

In December 2008, Wrocław City Council decided that the city would take part in the European Capital of Culture 2016 contest. Throughout the following year, an interdisciplinary team worked on a social diagnosis which became the basis for creating the contest application. The preparation of the application, which is the basic document enabling the participation in the contest for the ECC title, began in Wrocław in February 2010. The document, bearing the slogan "Spaces for Beauty," was forwarded to the Ministry of Culture and National Heritage six months later. In June 2011, Wrocław was announced as 
the winner, and the ECC 2016 office responsible for the preparation of Wrocław for the celebration of the year of 2016 was set up a year later.

"ECC 2016 Microgrants" is one of the European Capital of Culture 2016 celebration programs which aims to "include active residents of Wrocław and co-create Wrocław as part of the European Capital of Culture 2016 project by identifying, promoting and supporting social initiatives, as well as co-organising initiatives fitting the idea and concept of the ECC 2016" (Regulations Regarding Acquiring Partners to the Project Co-Organising Program by the Impart 2016 Festival Centre).

The program organisers specified its main goals. The program should:

- Refer to and comment on discussions being currently underway in Wrocław concerning bottom-up cultural initiatives, access to culture, Wrocław's local community issues (e.g. in estates) and the more common innovative animation and cultural initiatives,

- Help and support the progress of cultural and social events initiated by residents, especially those concentrated far from the city centre (this concerns mostly the administrative and financial support),

- Enliven the urban space, particularly by increasing the number of initiatives realized by the citizens (not by non-governmental organisations, cultural institutions, etc.),

- Act as one of the development mechanisms for permanent cooperation strategies between the citizens of Wrocław and cultural institutions,

- Refer to the cultural participatory budget concept and the main message included in the Wrocław's ECC 2016 contest application, namely the reinforcement of cultural participation understood in the broad sense, and counteracting exclusions from culture.

“Microgrants ECC 2016" program has been realized since 2014, when two pilot editions of the program with a relatively low budget and a low number of financed projects were implemented. Their number substantially increased in the following year, along with the amount of funds allocated to this initiative (although the maximum amount for the project (PLN 5000), which is approximately EUR 1200, remained the same since the program's inception). From 2014, 11 calls for proposals were announced, within which over 100 projects were realised in different areas of the city and the voivodeship.

\section{RESEARCH METHODOLOGY}

The goals of the evaluation project of ECC 2016 Microgrants were social and practical, as well as of a cognitive nature. The research procedure, along with the analysis of the materials collected, was held during the first two editions of the program. The conclusions were used to improve the initiative in the subsequent planned stages.

The three main goals for the research team included examining the ECC 2016 Microgrants functioning mechanism in the context of Wrocław's environ- 
ment, answering the question whether the program had fulfilled its assumptions, and finally, developing a catalogue for future recommendations. The whole research process aimed at providing answers to the following questions:

1. How is the initiative perceived by the diverse groups relevant to the program: the jury, the organizers, the applicants and the citizens of Wrocław?

2. How do the above-mentioned groups understand the critical concepts present in the Wrocław's European Capital of Culture contest application, such as culture, beauty, participation?

3. How can the program's functioning be improved in its subsequent editions?

4. Did the program accomplish its particular goals, which were highlighted on the project's home page by the organisers, during the realisation of the financed projects?

5. Were there any territorial regularities in relation to the contest applications?

Research environment. The research included mostly people who were directly associated with the realization of the first two editions of the ECC 2016 Microgrants program, namely:

1. Jurors who evaluated the submitted proposals for artistic and animation projects;

2. Program's beneficiaries;

3. Individuals employed in the program's implementation (those responsible for consulting about the program with interested potential beneficiaries, among others).

The following documents have also been analysed:

1. Wrocław's winning contest application, which granted the city the title of ECC 2016.

2. Rules of the ECC 2016 Microgrants program.

3. ("Regulations Regarding Acquiring Partners to the Project Co-Organising Program by the Impart 2016 Festival Centre").

4. The application form, as well the projects submitted in the first two editions of the program which successfully passed the formal evaluation.

5. Statistics and studies regarding the Wrocław space, and most importantly, its socio-cultural contexts, such as access to cultural institutions, the activity of non-governmental organisations and others.

The analysis of the above-mentioned documents aimed at providing answers to questions about the culture accessibility in different locations in Wrocław (the analysis was conducted mostly on the estate level) and the level of operations of cultural institutions and third sector organisations and their location in the city space. The analysis also focused on bottom-up activities, the language used in the program's application form and the understanding of ECC 2016 keywords. 


\section{Research Structure}

The research was split into three stages to guarantee constant verification and supplementation of the data already gained. Its objective was also to compare the evaluation results with the subsequent program's calls for proposals, their assessment, and realisation of the initiatives which gained funding. In every stage of the research qualitative in-depth interviews were conducted with the program's beneficiaries, the jury and the employees of the Impart 2016 Festival Centre, who were responsible for the ECC 2016 Microgrants program. In the first stage, research material was collected during a focus group interview with the members of the selection board. The first stage of the research also included an analysis of the already existing data, while the second and the third incorporated a transparent observation during the realisation of the program's financed projects. The last stage of the research featured an analysis of spatial distribution of the submitted and implemented initiatives.

It is worth noting that the project was fully commissioned and financed by the Impart 2016 Festival Centre.

\section{Research tools}

During the evaluation, the research team applied tools used in qualitative research, and tried to use diverse tools to provide a broad view of the phenomenon described herein. A poll, characteristic of quantitative studies, was included. Denzin and Lincoln (2010) justify the use of multiple methods in the following way:

Triangulation, that is using a variety of methods, reflects the attempt to further understand the examined phenomenon. (...) A combination of many methodological practices, empirical data, perspectives and observers in one research constitutes a strategy combining strictness, panache, complexity, richness and depth of every research (pp. 26-27).

By using diverse research strategies and perspectives (the members of the research team represented different scientific disciplines, such as pedagogy, cultural anthropology, cultural studies and philosophy, among others) as broad a spectrum of the researched phenomena as possible was attempted to be obtained.

The basic tools used in the research process included the analysis of the already existing data (qualitative and quantitative), qualitative interview, observation, cultural mapping and interview surveys.

Researchers also conducted focus group interviews with experts involved in the evaluation of contest applications, and on the map of the city of Wrocław we have marked sites relevant to the first two editions of the ECC 2016 Microgrants program: sites where the projects were to be carried out (all those which were given a positive mark in the formal evaluation), as well as those which were granted funding. By doing this, the research team wanted to answer the question about the presence of regularities in relation to spatial distribution of initiatives. 
Although the research project focused on several research questions, this article reports the conclusions which are related with the issue of space. The whole report is available online.

\section{CULTURAL MAPPING \\ - ECOC 2016 MICROGRANTS IN THE WROCŁAW SPACE}

The method of cultural mapping is integrally connected with engagement of the community in creating its cultural area. Turning attention on first edition of ECOC 2016 Microgrants in Wrocław in the context of culture mapping helps to create a Wrocław map with selected categories of places important from the perspective of the whole project analysis. Due to limited time and type of research cultural mapping method was an inspiration for us; however, some of its aspects were not applied to the research.

Cultural mapping engages society which identifies and documents local cultural resources. While researching we identified such elements of culture as: galleries, workshops, local events, but also memories, personal stories, values. (...) The crucial aim of this mapping is to help society identify (...) cultural diversity for regional economic and social development.

The whole research aimed to identify "places of power" in Wrocław understood as places with culture-producing potential, based also on bottom-up initiatives of citizens. Including in a map such vital points as culture houses, cinemas, theaters, etc. aimed at understanding whether the existence of this type of project affects cultural initiatives of citizens. The image of citizens' activity in the Microgrants program context has primarily diagnostic value, focusing on two most important issues:

1. Map as a basis to plan future lines of action for urban cultural policy.

2. Map as an identification of places with rich cultural offerings and those with a deficit. Were citizens from districts with developed infrastructure more active in seeking support for their micro grants ideas?

A supplement for the map is a qualitative analysis of interviews focusing on how to value an urban space by beneficiaries in the first and second recruitment of the project. The readers will find it in a following paragraph of this article.

Cultural mapping helped to illustrate the implementation of the Microgrants program in urban space and the information gathered became a supplement for the final study report. A study is a graphic presentation of the following data locations:

1. Location of all upcoming events submitted to the program,

2. Locations of events selected by the committee for implementation,

3. Location of existing cultural institutions, NGOs, etc.,

4. Location of Wrocław social problems on a district level. Information was gathered through the analysis of statistical data and publications on this topic (Kłopot, \& Skiba, 2006). 
As a result of inquiry a map of Wrocław was created. It is a starting point in discussions about civic participation, culture-producing role of cultural institution and NGO's as well as the 'cultural' condition of particular Wrocław districts. This can influence municipal policy on culture or programs which may strengthen and activate citizens. The final report includes the map with a key. The study on a spatial aspect of micro grants program emphasized a serious issue. The vast majority of projects submitted to the program were located in the very centre of the city. There was not a significant relevance between the existing cultural institutions or NGO's and the number of submitted applications. The dependency found during the analysis was simple: the closer to the city centre, the more applications were submitted. The exception was Nadodrze district with significant amount of applications. The Nadodrze district is currently under the process of revitalisation. As a result of this a lot of NGO's are located there, which is the very probable explanation for the increased number of applications. The very interesting point was that for some jurors the distant localisation of the proposed project was a reason for higher rating of the application. It is also visible in the map that although the majority of the projects were supposed to happen in the city centre, those selected for realisation were located in the more distant districts. It means that Microgrants can become not only a valuable way for diagnosing social demand on cultural offer in a city, but also an inspiration for citizens to set up some cultural activity in their neighborhood.

\section{TWO NARRATIVES ABOUT SITES - RECOVERING THE URBAN SPACE IN ACTION}

(all quotes used in this subsection come from the interviews carried out during the research)

One of the most problematic areas within the research and a reflection regarding the evaluation was urban space treated as a theme, a protagonist and a medium in the ECC 2016 Microgrants program. Indicating the sites of implementing the proposed initiatives on the map (both those which gained funding, and those not realised) from the first and second call for proposals was a starting point for the analyses. The issue of space has also surfaced in applications and interviews with the beneficiaries, the contest's jurors and employees of the ECC 2016 centre. It was very interesting hearing them convey their thoughts about the city, the needs of its citizens and the role of space in realisation of the program's main idea: spaces for beauty.

The respondents very often mentioned the issue of access (or lack thereof) to the infrastructure used by the citizens of Wrocław in leisure activities. One of the interlocutors clearly stated that the restricted access to culture on offer on her estate was a motivation for her to partake in this contest. The beneficiary wanted to "take matters into her own hands," also because she believed this situation hurt mostly children and parents: 
I felt an internal need. (...) I work in Księże [one of Wrocław's estates - A.W.] and I have been living there for twelve years. I am also the manager of this library, so in a sense I am a public figure and I observe such things. In the meantime, I have also become a mom. Some of my private needs, were kind of... I did not notice those things. And it really upsets me that, as a mom, I have to go to the city centre in order to show anything to my kid.

The same interviewee also raised the issue that when a particular institution organises cultural events, most of them are closed initiatives (e.g. activities in schools addressed only to the students of a given facility). In a conversation with the performer of the project in question ("Ready to START"), another important issue concerning the contemporary image of public space has surfaced, namely the low degree of citizens' integration, not only in the same estates, but also of close neighbours: "Because there is nothing happening, these people do not participate in the life on estates. They take care of everything... shopping, school in some sites. Even work. There is nothing going on to enable the people to meet somewhere."

The implementation of the project has resulted not only in a series of events and activities for the residents of Księże Małe, but also in a formation of a working group ready to further improve the estate. During the research, only one of the beneficiaries had voiced her reservations about the poor cultural offer in her immediate surroundings in a clear manner. A juror, who considered the fact that a given project was to be realised outside the city centre a relevant factor in the evaluation of applications, also commented on the disproportion in the access to city's cultural resources. "For me, the geographical indicator was also significant, although it was not a directly specified criterion. However, I rated higher projects from far-off estates, or held in estates lacking cultural activities, which does not necessarily mean peripheral estates. The estates of Przedmieście Oławskie, Huby, Pawłowice, and Księże Małe are really far from the city centre and it caught my attention right away."

Initiatives located in areas of Wrocław considered inferior, such as Nadodrze and Przedmieście Oławskie, have also been financed. The applicants did not hide the fact that this issue was important to them: "Well, we live in Nadodrze, and it is safe to say that this district is not the richest, so it is a chance for us to get ahead. I think that in the context of developing culture and supporting bottom-up initiatives it is very important."

Nadodrze is a peculiar estate because of its revitalization. The emphasis placed on artistic and social growth of the estate has been noticed by the beneficiary and the realisation of the microgrant fitted perfectly with the initiatives undertaken for years by various institutions and non-governmental organisations. The other place which evokes bad associations in most of the citizens of Wrocław is Przedmieście Oławskie, also known as the "Bermuda Triangle": "The Bermuda Triangle (...) is the most neglected estate in Wrocław. Everyone focuses on Nadodrze, and yet nobody mentions the «Triangle». That is why we wanted to concentrate on Przedmieście Oławskie, which holds many remnants of the past, such as stories and buildings." 
However, most of the awarded projects in the first two editions of the program were carried out across an area larger than an estate, and often involved the entire city, or even the Lower Silesia region. In terms of location, we have observed another interesting regularity connected to the ECC 2016 Microgrants, apart from the strong focus on close "neighbourhood," which characterized some of the projects and which was perceived by the research team as an enormous advantage. It was the attempt of alternative urban space storytelling in the realised projects. The beneficiaries spoke of their ideas to create an alternative to the official discourse on the space of Wrocław, which is no longer just a dynamic, European metropolis and the famous "meeting place." The goal of many initiatives was showing the city from a lesser known side and accentuating the beauty of areas that are not promoted as worth seeing: "our postcards do not show any of the known places. If it is the Wrocław of today, it would not be the Main Square or Old Town because there are a lot of places which depict [Wrocław] in a prettier and more genuine way." A similar reflection was shared by the applicant of a project covering the entire Lower Silesia, which involved taking photographs of unknown and forgotten monuments of the voivodeship not included in tourist guides. Apart from accentuating the beauty of such places, the respondents pointed to another strategy of creating alternative stories about the city, namely giving voice to the citizens.

One of the projects encouraged people connected to a particular estate to come up with a story about it, which would be later permanently exhibited in the public space. Another project focused on creating a collective diary of people of Wrocław. In the spatial dimension, the ECC 2016 Microgrants program has emphasised two important issues. First of all, they can become a valuable way of diagnosing social demand for the cultural events realized by the city. In order to achieve that, all the submitted applications would need to be accordingly analysed (What needs were reported by applicants? Are there any estates that are diagnosed by the citizens as lacking in these kinds of cultural events?).

Secondly, the microgrants can actually realise the "spaces for beauty" slogan, under which the Wrocław ECC contest application was prepared. According to the application, beauty is multidimensional and created by the human energy filling the space and resulting from interpersonal relations. Creating places for beauty requires the involvement of citizens who perceive space in their own individual way. From the interviews with participants it can be deducted that the perception of Wrocław's spaces is oftentimes different from the city's official presentation - a facade of monuments and great events - and this sensitivity to the forgotten urban space is the main focus of many of the initiator's contest projects.

The research team developed the catalogue of recommendations for future editions of the program. The recommendation concerned funding, methods of recruitment, how the competition documents should be constructed. When it comes to space, the basic recommendation was stronger emphasis on Microgrants sub local character. Applications are small and are often territorially 
limited. This feature can be turned into value - and it can be treated as a means to activate local societies at a neighborhood level (or different, not covering the entire city).

The research team recommend to integrate cultural activities within the Microgrants - on the basis of territorial aspects - with other activities taken by public institutions and non-governmental organizations in given Wrocław districts. Institutional and political context is favorable: Wrocław faces challenge i.e., on the one hand, the future of district committees, and on the other hand - growing popularity of the Wrocław Participatory Budget. Researchers recommend to deepen sub local identities - with particular consideration to their activities in culture, politics or education. Instead, the research team discourage municipal government actions which can weaken sub local identities to unite Wrocław identity.At an operational level - managing Microgrants program should be:

- More territorially diversified. Beneficiaries' service points and meeting points dedicated to the program should be localized in neighborhoods.

- In a similar way one can think of channels promoting the program: e.g. posters informing about micro grants could be at schools, parishes, seniors' clubs, shops, universities, culture houses and student clubs. In such places - and even, having calm weather conditions - one can organize public meetings informing about the program.

\section{CONCLUSIONS}

The activities depicted in this article were related to the celebration of the European Capital of Culture 2016 in Wrocław. Small-scale funding of citizen's cultural activities is a complete novelty here, although initiatives of this type are becoming more and more common in Poland. Low-budget, local activities of groups of people associated with a given place in a city can be viewed as the resistance shown by the people of Wrocław to the progressive unification of cultural endeavours, as well as the prevailing manner of understanding what culture participation is (that is of being a passive observer of events offered by various cultural institutions). Microgrants have encouraged the citizens to do something together with their neighbours, revitalize their estates' public spaces, and sometimes to even create one. They have also enabled overcoming of the official, promotional and touristic discourse about a city in which there was no place for spaces close to the project's performers. The initiatives described fully fit in with the trend of "new localism," which has been described as "educational, social and cultural activities taking place completely in a specific location, with the aim of gradual recovery of the place's significance and peculiarity in spite of progressing globalisation" (Gruenewald, \& Smith, 2010, p. xiii). Such initiatives have strong educational potential and let people who do not partake in the city's cultural life take responsibility for "their" piece of the occupied space, since these initiatives teach self-agency and encourage 
people to have a real influence on the inhabited area.

\section{REFERENCES}

1. Denzin, N. K., \& Lincoln, Y. S. (2010). Metody badań jakościowych 1 [Qualitative research methods]. Warszawa: Wydawnictwo Naukowe PWN.

2. Frysztacki, K. (2005). Między przestrzenią i publicznością miejską [Between the space and the city public]. In: A. Wallis, B. Jałowiecki, A. Majer, \& M. S. Szczepański (Eds.), Przemiany miasta: Wokót socjologii Aleksandra Wallisa [Transformation on the city. Around the sociology of Alexander Wallis] (pp. 151-158). Warszawa: Wydawnictwo Naukowe Scholar.

3. Grochowski, M. (2013). Wstęp do wydania polskiego. In: Ch. Landry. (Ed.), Kreatywne miasto. Zestaw narzędzi dla miejskich innowatorów [Creative city. Toolkit for urban innovators] (pp. 9-22). Warszawa: Narodowe Centrum Kultury.

4. Gruenwald. D. A., \& Smith, G. A. (2010). Place-Based Education in the Global Age. New York, London: Routledge. Taylor \& Francis Group.

5. Kłopot S. W., \& Skiba W., (2006). Atlas Społecznych Problemów Wrocławia [The Atlas of Wrocław's Social Problems]. Wrocław: Silesia.

6. Kowalski, K. (2013). O istocie dziedzictwa kulturowego - rozważania [Abouth the essence of cultural heritage - considerations]. Kraków: Międzynarodowe Centrum Kultury.

7. Filar P., \& Kubicki P. (Eds.). (2012). Miasto w działaniu. Zrównoważony rozwój z perspektywy oddolnej [City in action. Sustainable develompnet from the bottom-up perspective]. Warszawa: Instytut Obywatelski.

8. Montgomery, Ch. (2015). Miasto szczęśliwe. Jak zmieniać nasze życie, zmieniając nasze miasta [Good city. How to change our lives by changing our cities]. Kraków: Wysoki Zamek.

9. Sennett, R. (2008). Elastyczne miasto obcych sobie osób [Flexible city of strangers]. Le Monde diplomatique. Miesięcznik społeczno-polityczny, 4. Retrieved from http://monde-diplomatique. pl/LMD25/index.php?id=9.

10. Starosta, P., (1995). Poza metropolia. Wiejskie i małomiasteczkowe zbiorowości lokalne a wzory porządku makrospołecznego [Beyond the metropolis. Rural and small-town local communities and patters of macro-social order]. Łódź: Wydawnictwo Uniwersytetu Łódzkiego.

11. Szatan, M. (2012). Zanikanie przestrzeni publicznej we współczesnych miastach [The evanescence of public space in modern cities]. Palipsest. Czasopismo socjologiczne, 2, 91-102.

12. Theobald, P., \& Siskar, J. (2010). Place: Where Diversity and Community Can Converge. In: D. A. Gruenwald, \& G. A. Smith (Eds.), Place-Based Education in the Global Age (pp.197-220). New York, London: Routledge. Taylor \& Francis Group. 